\title{
Bir Efemera Türü Olarak Hatalı Kâğıt Para ve Hatalı Kâğıt Para Koleksiyonculuğu
}

\section{Erroneous Paper Money and Erroneous Paper Money Collection as an Type of Efemera}

\author{
Fatma Uyar ${ }^{1}$
}

${ }^{1}$ Sorumlu yazar/Corresponding author: Fatma Uyar (Öğr. Gör.),

Doğuş Üniversitesi, Meslek Yüksekokulu, Tibbi Dokümantasyon ve Sekreterlik, İstanbul, Türkiye E-mail: fuyar@dogus.edu.tr ORCID: 0000-0001-7816-4564

Başvuru/Submitted: 12.04 .2020

Revizyon Talebi/Revision Requested: 02.05.2020 Son Revizyon/Last Revision Received: 25.05 .2020 Kabul/Accepted: 27.05 .2020

Atıf/Citation: Uyar, F. (2020). Bir efemera türü olarak hatalı kâğıt para ve hatalı kâğıt para koleksiyonculuğu. Bilgi ve Belge Araştırmaları Dergisi, 13, 33-54.

https://doi.org/10.26650/bba.2020.13.02
$\ddot{\mathbf{O Z}}$

Koleksiyonlar, insanlar tarafından bilinçli ve düzenli olarak birçok sebeple bir araya getirilmişlerdir. Özelliklerine, türlerine göre sınıflara ayrılmış malzemelerden oluşturulan ve geçmişe dair her türlü bilgi içeren koleksiyonlar, estetik ve sanatsal açılardan da değere sahiptirler. Bu nedenle koleksiyonların toplumların kültürel, sosyal, siyasi gibi birçok yönüne ışık tutabilen, bilgi aktarıcı özellikleri mevcuttur. Geçici olarak bilgi vermek üzere üretilen ya da geçici olması niyetiyle üretilmese bile belli sebeplerden dolayı geçici hale gelen koleksiyon içindeki malzemelerin her biri efemera olarak kabul edilmektedir. Fakat son yıllarda özellikle kütüphaneciler ve arşivciler tarafından efemeraların geçici olmadığı dile getirilmektedir. Dolayısıyla koleksiyonlar sadece koleksiyoncuların değil, kütüphanecilerin ve arşivcilerin de ilgi alanına girmektedir. Bu çalışmada, koleksiyon çeşitlerinden biri olan hatalı kâğıt para koleksiyonları ele alınmış ve çalışma için öncelikle bir literatür taraması yapılarak kavramsal ve kuramsal bilgiler elde edilmiş; daha sonra nitel araştırma yöntemlerinden görüşme tekniği kullanılarak koleksiyoner Sayın Ülkü Feyyaz TAKTAK ile görüşme gerçekleştirilmiştir. Kendisiyle yapılan görüşme, hatalı kâğıt para koleksiyonlarının efemera çerçevesinde tartışılmasını sağlamak amacıyla yapııııışır. Çalışmanın, hem koleksiyoncular hem de kütüphane ve arşiv gibi bilgi merkezleri açısından anlamlı olacağı ve konuya, koleksiyonerin katkılarıyla yeni bir bakış açısı kazandıracağı düşünülmektedir.

Anahtar kelimeler: Nümismatik, efemera, hatalı kâğıt paralar, koleksiyon, koleksiyonculuk, aykırı paralar

\section{ABSTRACT}

Collections are established for a number of reasons in a conscious and orderly manner by people. Comprising of various materials, classified according to their types, and providing all kinds of information about the past, collections possess aesthetic and artistic values. Thus, collections can shed light on various aspects of societies, such as cultural, social and political aspects, and relaying information. Even though they are not always produced to provide information or to be temporary, collections become outdated due to certain reasons and each of the items in such collections are considered to be ephemera. In recent years, however, it has been stated that ephemera is not temporary, especially by librarians and archivists. Thus, collections are not only within the area of interest of collectors, but also librarians and archivists. In this study, the collection of faulty paper money, which is defined as the collection type, is discussed. Within the scope of this study, a literature review is carried out to acquire conceptual and theoretical knowledge; then the interview technique, from amongst the qualitative research methods, is selected and an interview with collector Mr. Ülkü Feyyaz TAKTAK is carried out. The interview is conducted to discuss erroneous paper money collections within the framework of ephemera. The study is thought to be meaningful for both collectors and information centers such as libraries and archives and provide a new perspective with the contribution of the collectors. Keywords: Numismatics, ephemera, erroneous paper money, collection, collecting, against moneys 


\section{EXTENDED ABSTRACT}

Collections provide information about the past and are made up of materials that are consciously and regularly brought together by people for many reasons and are classified into classes according to their characteristics and types. In addition, collections have a value in terms of aesthetics and artistry. For these reasons, collections shed light on societies in many aspects such as cultural, social and political. The materials that were created were used for a certain time in the past. In addition to the features that have lost their importance and / or have not been used due to various reasons, they may still be in use as well. While materials produced to provide temporary information are considered as ephemera, materials that are not produced to provide temporary information but which have become temporary for certain reasons are also considered ephemera. . But in recent years, it has been stated that ephemera are not temporary, especially by librarians and archivists. This is due to the fact that, the ephemera can be used based on various reasons in the future. For example, the development level of a city can be seen from time to time in photos taken, or the packaging of a technological product can provide information about the technological development process of the product. In addition, a ticket that is important during travel can be turned into evidence. Therefore, the subject of ephemera has been in the interest of librarians and archivists in recent years. In this study, one of the types of ephemera, the erroneous paper money collection was handled and a literature review was conducted for the study. As a result of the literature review, conceptual and theoretical information about collecting, money collecting, ephemera and erroneous paper money was compiled. Then, using the interview technique, which is one of the qualitative research methods, a meeting was held with collector Mr. Ülkü Feyyaz TAKTAK on the collection of erroneous paper money, on 04.01.2020. The interview was held with Mr. Ülkü Feyyaz TAKTAK, who has a collection of faulty money and who wants to share and provide information about faulty money through social media and seminars. The interview with him was made to ensure that the erroneous paper money collection was discussed within the framework of ephemera. The collector was asked 27 open-ended questions. The collection of faulty money and ephemera were the focus of the prepared questions. The questions were prepared centered on the collection of erroneous paper money and ephemera. In the interview questions, collecting and money collecting are also included. The outcomes of the study identified that the collections are formed on the collectors' mainly in-depth analysis of a specific topic. Therefore, the study highlights that a collection that provides information has become more than a hobby tool. Moreover, the results indicated the distinctive differences between fake and faulty money. In addition, the relationship between paper money and faulty paper money, ephemera-collectioninformation centres has not yet been fully understood by collectors; collectors develop individual methods to organize and protect their collections, and information is also among the results obtained. These are some of the conclusions reached as a result of both the literature study and the interview. It is thought that the study will be meaningful both for collectors and information centers such as libraries and archives in the context of erroneous paper money and ephemeral features, and will give the subject a new perspective with the contributions of the collector. 


\section{GíRIŞ}

İnsanların sosyal yaşamlarında geçici olarak kullanılmak üzere üretilen, kullanıldıktan sonra önemini kaybeden birçok materyal vardır. Düğünlere davet etmek üzere basılmış davetiyeler; konsere, tiyatroya, sinemaya gitmek ya da seyahat etmek üzere alınmış biletler gibi birçok malzeme sadece kullanılacağı tarih için önem teşkil ederler ve sonrasında bir işe yaramayacağı için çöp olarak değerlendirilirler. Fakat bu malzemeleri çöp değil; birer hobi aracı, onun da ötesinde ve esasen daha önemlisi, geçmişe -özellikle de popüler kültüre- dair bilgi veren kaynaklar olarak değerlendirip bir araya getiren; yani bunlardan bir koleksiyon oluşturan kişiler ve kurumlar da mevcuttur. Dışarıdan bakıldığında çoğu insan için sıradan bir vakit geçirme aracı ve/veya ilgi alanı olarak görülse de, koleksiyonlar üzerinde düşünüldüğünde, bu tür malzemelerin kullanıldığı döneme dair bilgi veren kaynaklar olduğu anlaşılmaktadır.

Efemera kelimesi "kısa süreli”, "geçici”, "gündelik yaşama ait”, "1vır zıvır” (Müzayede Dünyası, 2019) olarak tanımlanmaktadır. Bu nedenle, kelime anlamı itibariyle "geçiciliğe" ve/veya "önemsizliğe" karşılık geldiğini söylemek mümkündür. Öte yandan; amatör ya da profesyonel olarak toplanmış tüm koleksiyonların her bir parçası efemeradır. Ayrıca efemera konusu, efemera koleksiyonları zamanla tarih, arşiv, kütüphane gibi alanlarda araştırma yapanların ilgi alanına girmiş; araştırma mevzusu olmuştur. Peki, tanımlaması "önemsiz, gereksiz, geçici" gibi kelimelerle ifade edilen efemera, ilgilileri için neden araştırma konusu olacak kadar değerlidir? Koleksiyonerler "değersiz" olan malzemeler için mi bu kadar zaman ve emek harcamaktadırlar? Efemera koleksiyonlarının bir hobi olmak dışında hiçbir özelliği yok mudur?

$\mathrm{Bu}$ çalışma; yukarıdaki sorulara bir nevi cevap niteliği de taşıyacak şekilde efemeranın araştırma konusu olacak kadar değerli, efemera koleksiyonlarının bir hobi aracı olmaktan fazla özelliklere sahip birer bilgi kaynağı, hatta birer belge niteliğinde olduklarını ve efemerayı sadece "değersiz" ya da "geçici" olarak ifade etmenin yanlış olduğunu ileri sürmektedir. Koleksiyonerlerin "efemera koleksiyonlarıyla aslında toplumun kültür dünyası açısından son derece özel bilgi kaynakları derledikleri” yönündeki iddiaları, bu savın daha çok güç bulduğu en önemli dayanak noktasıdır.

Çalışmada efemera koleksiyonlarından hatalı kâğıt para koleksiyonu üzerinde durulmuştur. Çalışma kapsamında koleksiyoner Sayın Ülkü Feyyaz TAKTAK ${ }^{1}$ ile bir görüşme gerçekleştirilmiştir. Görüşmede kendisine açık uçlu 27 soru sorulmuştur. Koleksiyoner TAKTAK ile yapılan görüşme ve görüşme sırasında sorulara verdiği cevaplar çalışmada soru-cevap halinde belirtilmiştir. Çalışmanın bu kısmında sorular "kalın (bold) ve italik", cevaplar ise sadece "italik" olarak verilmiştir.

1 Koleksiyoner hakkında bilgi edinmek için; https://www.eczacibasi.com.tr/tr/Yoneticiler/UlkuFeyyazTaktak2 adresi incelenebilir. 
Görüşmede hatalı kâğıt para koleksiyonu hakkında bilgi almak ve koleksiyonun kendine özgü yanlarından yola çıkarak;

- Koleksiyonerliğin ne olduğu,

- Koleksiyonerlerin efemera kavramı, efemera türleri ve değeri hakkında bilgi sahibi olup olmadikları,

- Koleksiyonerlerin koleksiyon ve efemera kavramlarının birbirleriyle ilişkisinden haberdar olup olmadiğ 1 ,

- Koleksiyonerlerin efemera ile ilgili yapılan çalışmaları takip edip etmedikleri,

- Koleksiyonerlerin koleksiyonlarını düzenlerken ve korurken nasıl bir yöntem izledikleri,

- Hatalı kâğıt paranın ne demek olduğu,

- Hatalı kâğıt paralar ile sahte paralar arasındaki farkların neler olduğu,

- Hatalı kâğıt paraların hatalı olduğunun anlaşılma durumlarının neler olduğu,

- Efemera türü olarak hatalı kâğıt paraların değerlendirilmesi,

- Hataları kâğıt para koleksiyonlarının efemera kavramıyla ilişkisi hakkında bilgiler elde edilmesi,

amaçlanmıştır.

\section{Efemera ve Koleksiyonculuk}

\subsection{Efemera}

Efemeranın ortaya koyduğu çeşitlilik ve özellikler, dünyada ve Türkiye'deki birçok koleksiyoner ve araştırmacının efemera kavramı ve/veya konusuyla ilgilenmelerine sebep olmuştur. En basit ifadeyle ve şimdiye kadar genel bakış açısı olarak, "gündelik yaşama ait", "ıvır Zıvır" olarak nitelendirilebilecek kısa ömürlü, geçici materyaller (Somer ve Keskin, 2012, s. 441) şeklinde açıklanan efemera kavramına zamanla araştırmacılar farklı bakış açılarıyla yaklaşmış; yeni ve geniş tanımlamalar getirmiş; açıklamalar yapmışlardır. Bunlardan biri; bir efemera ansiklopedisi olan Encyclopedia of Ephemera'dır (2018). Kaynak, efemera tanımını; Yunanca "ephemeron (epi: hakkında, ilgili; hemera=gün)" kelimesinin çoğulu olduğunu ifade ederek açıklamaya başlamaktadır. Daha sonra, "kelimenin tam manasıyla, bazı kanatlı böceklerin yaptığı gibi gün boyu süren bir olaya atıfta bulunur" benzetmesiyle efemeranın gündelik yaşama dair her şeyi kapsadığı vurgusunu yapmaktadır. Ayrıca, danışma kaynağına yönelik yapılan genel bilgilendirmede ansiklopedinin efemerayı geçmişle bir bağlantı olarak gören herkes ve efemera koleksiyonerleri için tasarlandığı da ifade edilmektedir. Bu ifade; "efemeranın gündelik yaşama dair” olma vasfının ötesinde, geçmişle bir köprü kurma özelliğini temsil ettiğini ortaya koyması açısından dikkat çekici ve kıymetlidir. Tarihçilerin, arşivcilerin ve kütüphanecilerin 
efemera konusuyla ilgilenmelerinin en önemli sebebi de budur. Sarısır'ın, (2020) “İktisat Tarihi Yazımında, Efemera Olarak Tahvil ve Hisse Senetlerinin Önemi (Osmanlı'dan Cumhuriyet'e Örneklerle)" başlıklı makalesi ve Odabaş’ın (2018), “Arşivlerde ve Kütüphanelerde Yerel Kültürel Değerlerin Korunması Bağlamında Efemera Koleksiyonuna Karşı Sorumluluklar” isimli çalışması, efemeranın tarihi günümüze aktarma, geçmişle ilgili bilgi verme özelliğini ön plana çıkaran çalışmalardan bazılarıdır. Belirtilen çalışma, efemeranın birer bilgi kaynağı olma özelliğini, bir durumu, bir olayı kanıtlama yönünü de ortaya çıkarmaktadır.

Arşiv alanında hazırlanmış sözlüklerin efemerayı tanımlarken "belge” kavramını kullanıyor olmaları da efemeranın bir konu için bilgi ve kanıt aracı olma özelliğini desteklemektedir. Bu duruma örnek teşkil eden çalışmalardan biri de; Karakaş, Rukancı ve Anameriç'in (2009) hazırladıkları "Belge Yönetimi ve Arşiv Terimleri Sözlügüüdür. Sözlükte efemera; "genellikle örnek veya model olarak tutulan, geçici değere sahip resmi olmayan belgeler" ve "otobüs/ sinema ve piyango biletleri, spor toto kuponları, gazete nüshaları, tanıtım broşürleri, mektuplar, kartvizitler, lokanta menüleri, banka dekontları, çikolata ve sakızlardan çıkan kartlar, sigara kâğıtları, posterler, fotoğraflar, kartpostallar, düğün davetiyeleri gibi gündelik hayatın ayrıntılarını belgeleyen kısa ömürlü küçük ve geçici belgeler” olarak açıklanmaktadır (s. 29). Başka bir arşiv sözlügü olan "A Glossary of Archival and Record Terminology" (2005) kaynağında da efemeranın, belirli ve sınırlı bir amaç için oluşturulmuş ve genellikle kullanımdan sonra atılmak üzere tasarlanmış, çoğunlukla basılı belgeler, malzemeler oldukları ifade edilerek, efemeranın "belge” olarak tanımlandığı anlaşılmaktadır. Young'ın (2003) yapmış olduğu "Evidence: Toward a Library Defination of Ephemera" adlı çalışmasında, günlük hayatta kullanılan gündelik tüm eşyanın efemera olduklarına, efemeranın da kanıtsal özelliğine değinilerek arşiv ve kütüphanecilerin efemera tanımlama, sınıflama, koruma noktasındaki görev ve sorumluluklarına vurgu yapmaktadır. Bu yönüyle Young'ın çalışması da efemeranın kütüphane ve arşiv malzemesi olma özelliğini ifade eden bir yaklaşım ortaya koymaktadır.

Yukarıda verilen tanımlar ve açıklamalardan da efemeranın “1vır zıvır”dan ibaret olmadı̆̆ı; bilgi kaynağı ve belge olmanın yanı sıra bir olayı/durumu kanıtlayabilir özelliğinin olduğu anlaşılmaktadır. Dolayısıyla efemera; tarihçilerin, popüler kültür araştırmacılarının, arşivcilik ve kütüphanecilik alanının ilgilendiği/ilgilenmesi gerektiği materyallerdir. Hatta arşiv alanında çalışan uzmanlar, efemera ile ilgili "arşivsel efemera" terimini üreterek, efemeraya arşivcilik alanına özgü bir tanım getirmişlerdir. Bu tanıma bakıldığında arşivsel efemera; "çok sayıda baskısı yapılan ve dağıtılan ancak kitap, broşür ve dergi gibi malzemenin dışında kalan, özel bir zamanda ve özgün bir amaç için üretilen, acil bir kurumsal eylemi gerektirmeyen, dosya bağı kopartıldığı ya da olmadığı için parça halinde derlenen ve sonradan oluşturulmuş bir koleksiyon içine yerleştirilebilen, standart arşiv sınıflandırma ilkeleri uygulan(a)mayan, yararlılığı değişken olan, birincil ve ikincil kaynak niteliği taşıyan, gerçek değeri zamanla anlaşılan yazılı, basılı, resimli ve elektronik materyaldir.” (Somer ve Keskin, 2012, s. 446). 
Arşivsel efemera için yapılan bu tanım incelendiğinde efemeraya arşivcilik mesleğine özgü kavramsal bir netlik kazandırıldı̆̆ı; tüm yönleri ve özelliklerine vurgu yapılarak bir tanım ortaya konulduğu anlaşılmaktadır.

Efemera ile ilgili tanımlar incelendikten sonra efemeranın nitelikleri şu şekilde ortaya konmuştur (Somer ve Keskin, 2012, ss. 444-445);

1. Kısa süreli bir amaç için ve düzensiz olarak üretilirler,

2. Acil kurumsal bir faaliyete ihtiyaç duymazlar,

3. Biriktirilmek üzere üretilmezler,

4. Genellikle basılı, yazılı ve resimlidirler; fakat günümüzde elektronik de olabilmektedirler,

5. Bir amaç için özel olarak üretilirler,

6. Kısa ömürlüdürler ve devamları yoktur,

7. Resmi ve gayri resmi olabilirler,

8. Gerçek değerleri zamanla anlaşılır,

9. Genellikle konuya ilgi duyan koleksiyoncular tarafindan koleksiyon malzemesi olarak değerlendirilirler,

10. “Ivır zıvır” ürünler olarak görülüp değersiz addedilirler,

11. Kütüphanecilik ve arşivcilik tekniği açısından değerlendirildiğinde, bilgi kurumlarının standart uygulama ilkelerine göre tasnif edil(e)mezler,

12. Yararlılığı değişkenlik gösterir,

13. Birincil ya da ikincil kaynak olarak değer görürler,

14. Dayanıksızdırlar,

15. Genel bakış açısı dolayısıyla günlük yaşamın bölük pörçük (parçalar halindeki) dokümanlarıdırlar.

9. maddede, efemeranın koleksiyon malzemeleri olarak değerlendirildiği söylenmektedir. Koleksiyoncular, ilgilerini çektiği konular ile alakalı materyalleri bir araya getirerek oluşturdukları efemera koleksiyonlarıyla bir nevi bilgi kaynaklarını ortaya koyarlar. Bu bağlamda, hem konu hem de materyal üzerinde uzmanlaşmış efemera koleksiyoncuları vardır (Somer ve Keskin, 2012, s. 439).

\subsection{Koleksiyonculuk}

Koleksiyonculuk en temel yaklaşımla “derlemcilik” (Güncel Türkçe Sözlük, 2020) şeklinde açıklanmaktadır. Anlam karşılığı her ne kadar tek kelime ile ifade edilse de koleksiyonculuk kavramının içeriğini ayrıntılı olarak betimleyen açıklamalar da getirilmiştir. Genel olarak 
değerli nesnelerin ve sanat eserlerinin toplanmasına, biriktirilmesine ve saklanmasına yönelik bir hobi olarak ifade edilen koleksiyonculuk, aslında ince bir zevk ile bilinçli bir toplama güdüsünün birleşimidir (Çantay, 2019). İlgi duyulan alana göre çeşitli ürün, eşya, nesne ve objeleri belirli bir düzene göre bilinçli olarak biriktirme faaliyetine koleksiyonculuk denmektedir. Araştırma ve geliştirmeye yönelik bir hobinin ürünü olan koleksiyonlar çok geniş ve çeşitli materyallerden meydana gelebilmektedir. Örneğin; deniz kabuklarını biriktirmek bir koleksiyonculuk iken lüks otomobiller de koleksiyon ürünü olabilmektedir. Kişinin ilgisi, imkânları ve zevk anlayışına göre koleksiyon türleri de çeşitlilik gösterebilmektedir. Koleksiyon hobisi, genellikle toplanan nesnelerle ve temsil ettikleri kültürlerle de bağlantılıdır. Örneğin; kartpostal toplamak, genellikle farklı kültürlere ve yerlere olan ilgiyi yansıtır. Bu nedenle bazı eğitimsel faydaları söz konusudur (Makaleler, 2020).

Koleksiyonculuk geleneğinin tarihi incelendiğinde, başlangıcının bir hayli eskilere dayandığı anlaşılmaktadır. Antik dönemde, Yunan ve Mezopotamya medeniyetlerinde, tapınaklara adak olarak sunulan kıymetli objelerin yapının hazine binalarında saklanması bu geleneğin ilk örneklerini oluşturduğu ifade edilmektedir. Daha sonra yöneticiler de ülkenin siyasi ve askeri gücünü göstermek adına, savaşlarda kazandıkları ganimetleri saraylarında toplamaya başlamışlardır. Dini ve siyasi temele dayalı bu ilk koleksiyonlarda gösterişli ve üstün nitelikli bir işçilik sergileyen parçalar tercih edilmiştir (Çantay, 2019).

Daha önce de ifade edildiği üzere çeşitli türden materyallerle koleksiyonlar oluşturulabilmektedir. Bunlardan biri de para koleksiyonlarıdır.

Para koleksiyonculuğu denilince akla gelen ilk "nümismatik" kavramı olmaktadır. Nümismatik, para manasına gelen Latince "nummus" kelimesinden gelmektedir. Para, madalya ve jetonların betimlenmesi ve tarihiyle uğraşan bilimdir (Darphane ve Damga Matbaası Genel Müdürlügüü, 2018). Para koleksiyonculuğu da genel olarak nümismatik olarak adlandırılır (Türk Nümismatik Derneği, 2012). Türkçeye Batı dillerinden numismatik olarak geçen para koleksiyonculuğu yerine Osmanlı Türkçesinde meskûkât (sikkenin çoğulu) sözcüğü de kullanılmaktadır (Tarih Bilimleri, 2017). Nümismatik, tarihe yardımcı bir bilim dalı (alt bilim dalı olarak da geçer) olarak kabul edilmektedir. Nümismatik, eski paraları incelemekte; bu paraların ait oldukları medeniyetlerle ilgili bilgi edinilmesinde tarih bilimine yardımcı olmakta ve bu sebeple tarihe yardımcı bir bilim dalı olarak kabul edilmektedir (Tarih Rehberiniz, 2020). Bu bilim dalında uzman kişilere de "Nümismat” denilmektedir (Türk Nümismatik Derneği, 2012).

İlk antik para koleksiyonları, Rönesans döneminde, Roma ve Yunan tarihindeki ünlü kişilerin portrelerini araştıran hümanistler tarafından oluşturulmuştur. Bu koleksiyonlara zamanla eski siteler ${ }^{2}$ tarafından bastırılan, yorumlanması daha zor paralar da eklenmeye başlanmıştır. Daha sonraları, Yeniçağ para ve madalyaları da toplanmıştır. Tüm bu nesnelerin anlaşılması

2 Site, İlk Çağda kendi yasalarıyla yönetilen bir veya birkaç kentten oluşan devlet. Erişim adresi: https://sozluk.gov.tr/ 
ve sınıflandırılması, nümismatik biliminin temelini oluşturmaktadır. Türkiye'de nümismatik biliminin gelişiminde ilk rol oynayan Abdüllatif Suphi Paşa'dır (1818-1886) ve kendisi ilk Türk nümismatı olarak şöhret bulmuştur (Darphane ve Damga Matbaası Genel Müdürlüğü, 2018).

Para koleksiyonculuğu, dünyanın özellikle çok gelişmiş ülkelerinde (ABD, Kanada, İngiltere gibi) oldukça yaygındır. Bahsedilen ülkelerdeki nümismatik derneklerine veya örgütlerine çok sayıda insan üyedir. Ciddi manada para koleksiyonculuğu, derin bir kültürel altyapıyı, yoğun araştırma yapmayı, nümismatik biliminin ortaya çıkardığı gerçekleri yakinen takip etmeyi, arkeolojik alanda gerçekleştirilen çalışmalarla yakından ilgilenmeyi gerekli kılan bir uğraştır. Para koleksiyonculuğu, yalnız ekonominin kıtlık kuralından yola çıkılarak sadece bir servet biriktirme olgusu olarak görülemez. Bu uğraş; insanın çok yönlü olarak kendisine yatırım yapmasını ve kendisini geliştirmesini sağlayan özel nitelikli bir uğraştır (Darphane ve Damga Matbaası Genel Müdürlüğü, 2018).

Türkiye' de para koleksiyonculuğu; gelişmekte olan bir uğraştır. Henüz yeteri kadar yaygınlık kazanmamıştır. Şu an için gelişmiş ülkelerle kıyaslanamayacak ölçüde az kişi tarafından para ve hatıra para toplanmaktadır (Darphane ve Damga Matbaası Genel Müdürlüğü, 2018). Türkiye'de Türk Nümismatik Derneğ $i^{3}$ ve İzmir Nümismatik Derneği ${ }^{4}$ gibi kuruluşlar para koleksiyonculuğunun gelişim sürecine katkı sağlamaktadır. Bunun yanı sıra, konusu para koleksiyonculuğu olan dergilerle de para koleksiyonculuğuna ilgi duyanlara rehberlik edilmeye çalışılmaktadır. Söz konusu dergiler, alan ilgilileri için değerli birer bilgi kaynağıdır. Ayrıca; para koleksiyonculuğuna gönül vermiş, ilgi duyan kişiler ve/veya koleksiyonerlerin birbirleri ile iletişim kurduğu, para koleksiyonculuğu hakkında bilgilerin paylaşıldığı forumlar; paraların ve paraları korumak için kullanılacak malzemelerin (klasörler, paraları temizleme ürünleri vs.) satışa sunulduğu web siteleri mevcuttur.

Para koleksiyonun bir türü olan hatalı kâğıt para koleksiyonları pek bilinmeyen ama önemli koleksiyonlardan biridir.

\subsubsection{Hatalı Kâğıt Para Koleksiyonculuğu}

Hatalı kağıt paralar ile ilgili literatür araştırması yapıldığında konuyla alakalı yapılan çalışmaların nadir olduğu görülmektedir. Tunç Buyurgan’a ait olan “Aykırı Paralar: Denemeler, Erörlüler, Sahteler, Para- Biletler, Paramsılar” adlı kitap da, içerisinde hatalı paralar ile ilgili bilgileri barındıran örnek çalışmalardan biridir. Piyasada kullanılan paralar dışındaki tüm paraları "aykırı paralar" kavramı altında toplayan Buyurgan (2007), kitabında hatalı kâğıt

3 Türk Nümismatik Derneği; nümismatik ve para koleksiyonculuğuna ilgisi olan 22 kişi tarafından 1968 yılında kurulmuştur. Merkezi İstanbul'dur. Erişim adresi: https://web.archive.org/web/20130805214301/http://www. turknumismatik.org.tr/tuzuk.pdf

4 İzmir Nümismatik Derneği; nümismatik ve para koleksiyonculuğuna ilgisi olan 8 kişi tarafından 1996 yılında İzmir Konak’ta kurulmuştur. Erişim adresi: http://www.izmirnumismatik.org/index-tr.html 
paralara ayrıntılı bir şekilde yer vermiştir. Kendisine ait olan para koleksiyonundan yola çıkarak hazırladığı çalışmada, para basımının her aşamasında güvenlik unsurunun üzerinde dönemin tüm teknik, artistik ve finnansal imkânlar seferberlik edilerek çalışılmasına rağmen dünyanın her ülkesinde olduğu gibi Türkiye'de de hatalı paraların piyasaya çıkabildiğinden bahsedilmektedir. Ayrıca hatalı paraların saklanmaya ve sergilenmeye değer oldukları ve mükemmel birer koleksiyon malzemesi olarak da müzayedelerin en özel parçaları oldukları ifade edilmektedir (2007, s. 69).

Buyurgan'ın kitabında, kâğıt paraları hataları noktasında türlere ayrıldığı görülmektedir. Bu kapsamda hatalı kâğıt para türlerine bakıldığında şu şekilde katagorize edildiği görülmektedir (2007, ss. 70-95):

\section{a) Nümeratör Hatalar}

Numaraların basımıyla ilgili gerçekleştirilen yanlış basımlar, kâğıt paralarda görülen hatalardandır. Numaraların paralara hiç vurulmamış olması, numaraların yanlış yere vurulması, numaraların vurulmuş olmasına rağmen mürekkep bittiğinden okunamaması, numaraların üstüne başka numara vurulması, numaraların birbirinden farklı olması gibi çeşitli sebeplerden dolayı kâğıt paralar hatalı olarak basılmaktadır.

\section{b) Basım Hataları}

Basımda yapılan yanlışlar da hatalı kâğıt paraların ortaya çıkmasına sebep olmaktadır. Eksik baskı neticesinde gerçekleştirilen hatalar bunlardan biridir. Mürekkebin bitmesinden kaynaklanan basım hataları, basılacak zeminin üzerinde başka bir zemin bulunmasından kaynaklı hatalar, basılacak zeminin buruşuk, yırtık, katlı veya yağlı olmasından kaynaklanan hatalar, paranın baskılardan bir veya birkaçına girmemesinden kaynaklanan hatalar neticesinde kâğıt paraların eksik bir şekilde basıldığı söz konusu olmaktadır.

Fazla baskı da basım hataları başlığı altında ele alınan hata türlerinden biridir. Paranın bir yüzüne ters olarak diğer yüzünün tekrar basılması, paranın bir yüzüne düz olarak diğer yüzünün basılmasının tekrar basılması gibi sebeplerden dolayı oluşan fazla baskılar da hatalı kâğıt paraların oluşumuna sebep olmaktadır.

Renk farkları da hatalı kâğıt paraları ortaya çıkaran sebeplerden biridir. Baskıda kayma, bütün baskıların aynı ölçüde kayması (veya baskın rengin kayması) gibi durumlar renk farklarının oluşmasına neden olmaktadır.

Diğer bir baskı hatası da, flu baskı sebebinden kaynaklanan bir hatadır. Paraların birkaç baskıyı üst üste alamamasından kaynaklı flu bir görünüm oluşmaktadır. Bu durum da basım hatasından kaynaklanan hatalı kâğıt paralar sınıfına girmektedir. 


\section{c) Kesim Hataları}

Kâğıt paraların hatalı olmasına sebep olan başka bir durum da kesim hatalarıdır. Kesim hataları neticesinde ilginç kâğıt paraların ortaya çıktığı görülmektedir. Parayı kesim esnasında kaymadan kaynaklı hatalar, tabakanın yanlış taraftan kesime verilmesiyle oluşan ve kesimde dönme olarak ifade edilen hatalar, tabakanın kesime düz girmesi gerekirken, yanlışlıkla katlanarak girmesi sonucunda paranın üzerinde kalan fazla parçadan kaynaklanan ve kulaklı para olarak adlandırılan hatalar, paralar kesime girmeden önce oluşturulan tabakaların kesim esnasında kaymasından kaynaklı tabaka numaraları hataları kesim hataları olarak kabul edilmektedir.

\section{d) Filigran Hataları}

Kâğıt paralarda olan hatalardan biri de filigran hatalarıdır. Bazı kâğıt paralarda filigranların olması gereken yerde olmamasından kaynaklanan hatalar bu kapsamda değerlendirilmektedir.

\section{e) Emniyet Teli Hataları}

Paralarda bulunan şeritlerin hatalı basılmasından kaynaklı hatalı kâğıt paralar meydana gelmektedir.

\section{f) Klişe Hataları}

Kâğıt paraların klişe hatalarına örnek ile açıklık getirilmesi gerekirse; Atatürk’ün saç diplerinin beyaz kalması söylenebilir.

\section{g) Hata Olup Olmadı̆̆ı Tartışılanlar}

Paranın hatalı olup olmadığının tartışılması, paranın üzerindeki önemli kişiler ile ilgili bilgiler konusunda ihtilafa düşülmesiyle alakalıdır. Eğer bu kişilerle ilgili bilgiler (doğum tarihi gibi) kaynaklarda net değilse; paranın hatalı olup olmadığı da tartışılmaktadır.

Yukarıda açıklanan tüm hatalar; hatalı kâğıt paraların oluşum sebepleri ve türleriyle ilgili bilgi vermektedir. Bu özellikleri sebebiyle hatalı kâğıt paralar, para koleksiyoncularının da dikkatini çekmektedir.

\section{Yöntem}

Çalışmada hatalı kâğıt para koleksiyonları hakkında bilgi almak amacıyla koleksiyoner Sayın Ülkü Feyyaz TAKTAK ile görüşme gerçekleştirilmiştir. Hatalı kâğıt para koleksiyonu ile alakalı görüşmenin Sayın Ülkü Feyyaz TAKTAK ile gerçekleştirilmesinin sebebi, Türkiye'de hatalı kâğıt para koleksiyonu oluşturan, hatalı kâğıt para koleksiyonu ile ilgili elde ettiği bilgileri, koleksiyon parçalarını, hem sosyal medya hem de verdiği seminerler aracılığı ile 
paylaşan en önemli kişilerden biri olmasıdır. Hatalı kâğıt paralarla ilgili literatür anlamında araştırma yapıp konuyla ilgili kütüphane oluşturması da önemli noktalardan biridir. Görüşme talebi, kendisine sosyal medya aracılığı ile iletilmiştir. Görüşmede kendisine toplamda 27 soru sorulmuştur. Sorular hazırlanırken ağırlıklı olarak hatalı kâğıt para koleksiyonu ve efemera hakkında bilgi almak amaçlanmıştır. Fakat hatalı kâğıt paraların ne olduğunu daha iyi anlamak ve koleksiyonerlik ile efemera ilişkisini ortaya koymak adına öncelikle koleksiyonerlik, para koleksiyonerliği hakkında bilgi almak istenmiştir. Dolayısıyla sorular bahsedilen amaç ve istekler göz önünde bulundurularak hazırlanmıştır. Sorular hazırlandıktan sonra, görüşme gerçekleştirilmeden önce sosyal medya aracılığı ile koleksiyoner Sayın Ülkü Feyyaz TAKTAK ile paylaşılmıştır. Daha sonra koleksiyonerin uygun olduğu tarih belirlenerek (04.01.2020) görüşme gerçekleştirilmiştir.

Görüşme tamamland1ktan sonra elektronik posta aracılığg ile görüşmenin son hali koleksiyoner Sayın Ülkü Feyyaz TAKTAK ile paylaşılmış; gerektiği noktalarda eklemeler ve düzeltmelerin yapılmasıly görüşme son şeklini almıştır.

\section{Bulgular}

Çalışmanın bu kısmında koleksiyoner Sayın Ülkü Feyyaz TAKTAK ile hatalı kâğıt para koleksiyonu ve efemera üzerine yapılan görüşme aktarılmaktadır. Sayın Ülkü Feyyaz TAKTAK'a yöneltilen sorular “kalın (bold) ve italik", cevaplar ise sadece "italik" olarak metinde verilmiştir.

\section{Koleksiyonerlik sizce nedir?}

Dünün ve bugünün kültürünü geleceğe taşıyan "emanetçiler” dir koleksiyonerler. Koleksiyonerlik bir konuyu derinlemesine ele alarak o konuyu incelemek demektir. Koleksiyonerler de koleksiyonlarını derin bilgi istek ve ihtiyaçlarından ötürü oluşturmaktadırlar. Gerçek koleksiyonerler ticaret için kolay kolay koleksiyon oluşturmazlar. "Portakal'ın Bence bir kişinin kafasında bir koleksiyon fikri ve yüreğinde sevgi olmuşsa, bu o kişiye koleksiyoner denmesine yeter.” ifadesi bu bakımdan anlamlıdır.

\section{Koleksiyon edinmeyi ve/veya oluşturmayı ne zaman ve neden düşündünüz?}

On yaşımdan itibaren hemen her şeyi biriktirmeye başladım. Koleksiyon oluşturmamın birkaç sebebi var. Öncelikle benim hiçbir şeyi atamama gibi bir huyum var. Bununla birlikte iş stresinden uzaklaşmama vesile olan bir hobidir koleksiyon oluşturmak benim için. Bana huzur veriyor ve zamanımı mutlu geçirmemi sağlıyor. Emekli olduğumdan bu yana sıkılmaya hiç zamanım olmadı koleksiyonlarım nedeniyle.

3. Koleksiyonunuzu nasıl edindiniz (satın alma, hediye vs.)?

Ben koleksiyonumu tüccarlardan satın alarak oluşturuyorum ve müzayedelere (internet ortaminda ve/veya canlı olarak) katıliyorum. 


\section{Elinizdeki koleksiyonun (tür olarak) ne olduğunu düşünüyorsunuz?}

Elimdeki koleksiyonların hepsinin bir bütün olarak efemera koleksiyonu olduğunu düşünüyorum.

\section{Para koleksiyonculuğu kendi içinde gruplandırılıyor mu? (Para koleksiyonerliğinin türleri var mıdır?)}

Para koleksiyonları çok çeşitli türlere ayrllabilmektedir. Bunlardan; sahte paralar (kağıt paralar, madeni paralar, jetonlar), taslak ve prova paraları tedavüle sürülmeyen paralar, pazarlamacı numuneleri, deneme baskılar (renk, motif/klişe denemeleri), kilise paraları, vapur paraları, tramvay paraları, köprü paraları, cami paralarl, havra paralarl, film / tiyatro paralart, promosyon ve reklam paralarl, oyun paralar şeklinde bahsetmem mümkün.

\section{Koleksiyonunuzu toplarken malzeme ve konu hakkında bilgiye sahip miydiniz?}

Benim ana koleksiyonum "T.C. hatalı pulları" alanında. Hatalı kâğt paralarla ilgili bir bilgiye sahip değildim başlangıçta. Hatalı kâğıt paraları toplamaya başlama hikâyeme de -bahsettiğim üzere-tesadüfen başladım. Doğal olarak zamanla bilgi edindim koleksiyonumla ilgili.

\section{Sahte para ile hatalt para birbirinden nasıl ayrılmaktadır?}

Sahte para elime hiç geçmedi; fakat bir paraya sahte diyebilmemiz için filigranı olmaması, emniyet şeridinin olmaması, bir de gerçek paralardan biraz farklı basılmış olması gerekir (birebir aynısı basılırsa cezası daha büyük oluyor diye biliyorum). Hatalı paralar ise; fark edilmeden gerçekleştirilen basım ya da kesim yanlışlıklarıyla oluşan paralardır.

\section{Hatalı kâğıt para toplama merakınız nasıl oluştu?}

Aslında meraktan çok tesadüf eseri hatalı para koleksiyonuna başladım. Benim bir pulcu arkadaşım vardı. Dükkânına haftada bir gün uğrardım. Hatalı pullar eline geçtikçe alırım kendisinden. Herhalde en az otuz sene önce yine yanına uğradı̆̆ım bir gün otururken bir genç dükkândan içeri girdi ve dükkân sahibi arkadaşıma "Abi ben askere gidiyorum ve paraya ihtiyacım var. Bunları benim için satar mısın?" diyerek tezgâha bir zarf bıraktı. Ben de merak ettim, arkadaşıma onların ne olduğunu sordum. O da bana, hatalı pullar toplamamdan ötürü benim ilgi alanıma girebileceğini ve zarftakilerin hatalı kâğıt paralar olduğunu söyledi. Paraları da görünce ilgimi çekti. Çünkü paraların her biri biricik, ikincisi yok. Gence kaç para istediğini sordum, kendisi de bir rakam söyledi ve pulcu arkadaşımın fiyat teyidinden sonra getirdiği hatalı paraların hepsini o an satın aldım ve böylelikle hatalı para koleksiyonculuğu serüvenim başlamış oldu. 


\section{Koleksiyonunuzu nasıl düzenliyorsunuz?}

500 tane klasörüm var, tüm koleksiyonlarımın hepsini ayrı ayrı klasörlere yerleştiriyorum. Hatalı / erörlü kâğıt para koleksiyonum özelinde yanıtım ise; hatalı paralarımı ait oldukları emisyonlara göre ayırıp (kısaca tedavül edildikleri tarihleri göz önüne alarak) stralayıp (o emisyonda da küçük değerden büyüğ̈̈ne göre sıralayı) klasörlere yerleştiriyorum.

\section{Düzenleme konusunda yardım aldını mı?}

Herhangi bir yardım almadım, kendi yöntemimle düzenledim. Herkese de kendi koleksiyonlarını kendilerine özgü yöntemlerle düzenlemelerini öneririm.

\section{Hatalı paranın kıymetlendirme (satma, satın alma) şekli nasıldır?}

Hatalı paraların nadir olma durumuna göre klymetlendirme yapılmaktadır. Paraların hata türü, paranın kondüsyonu, fiyatını belirleyen etmenlerin başında gelir. Nümanismatik müzayedelerinde satışlar söz konusu olmaktadır. Hatalı paraların gerçek klymetlendirmelerini ögrrenmek için müzayedeler önemli organizasyonlardır. Her biri, hatalı türünün tek örneği olduğundan katalog fiyatları yoktur. Fiyatı alıcı ile satıcı arasinda belirlenir.

\section{Hatalı kâğıt paralar arasında gruplandırma var mıdır?}

Literatürde bir gruplandırma yok. Ben hatalı paralarımı; numarası olmayanlar, ${ }^{5}$ kulaklı olanlar, ${ }^{6}$ baskı eksiği olanlar, ${ }^{7}$ çoklu baskı olanlar, ${ }^{8}$ nadir şekilli olan paralar, ${ }^{9}$ gibi başlıklar altında sınıflandırıyorum. Dediğim gibi normalde böyle bir gruplandırma yok.

\section{Bu tarz koleksiyon oluşturanlarla bir iletişiminiz ve iletişim ağınız var mıdır?}

Hatalı para koleksiyonu oluşturanlarla sürekli kurduğumuz bir iletişim ă̆ımız yok; fakat "Collection” isimli bir kulüp var. Her konuda koleksiyon yapan koleksiyonerlerin oluşturduğu çok klymetli bir kulüp. Kulüp başkanımız Facebook'taki paylaşımlarımdan dolayı benden hatalı kâğıt paralar konusunda bir sunu hazırlamamı istedi. Ben de 3 Aralık 2019'da bir sunu gerçekleştirdim. Orada gördüm ki; hepsi koleksiyoner olmasına răgmen, katılanların yüzde doksanından fazlası ilk defa hatalı kâğıt para gördü. İçinde kâğıt para koleksiyonerleri de vardı. Dolayısıyla sosyal medya ile seminer ile bir nevi iletişim gerçekleştirmiş olduk bu konuya gönül verenler arasında. Ayrıca Facebook'ta da bu toplantının fotoğrafları yayımlandı ve seminerin başlı̆̆ ve benim tarafimdan verildiği belirtildi. Orada da yansıması

5 Çalışmada "fotoğraflar" başlığı altında "ek 1" olarak yer verilmiştir.

6 Çalışmada "fotoğraflar” başlığı altında "ek 2" olarak yer verilmiştir.

7 Çalışmada "fotoğraflar" başlığı altında "ek 3"olarak yer verilmiştir.

8 Çalışmada "fotoğraflar” başlığı altında "ek 4" olarak yer verilmiştir.

9 Çalışmada "fotoğraflar” başlığı altında "ek 5" olarak yer verilmiştir. 
aldiğı olumlu yorumlar ve de "beğeni"ler şeklinde oldu. Bunun dışında, Colleciton Dergisi'nde benim bir köşem var "Ülkü Feyyaz TAKTAK'ın kutularından” ismiyle, o köşe yazılarımla da ilgilenenlerle iletişime geçmiş oluyorum.

\section{Hatalı para koleksiyonerleri arasında bir hediyeleşme var mı?}

Benim hediye almışlı̆̆ım ya da hediye vermişliğim yok. Her birinin seri numarasının tekliği sebebiyle öyle bir hediyeleşme olduğunu düşünmüyorum; çünkü aynı hatalı paradan bir ikincisi (çok istisnai durumlar haricinde), fazlası yok hiçbir koleksiyonerin.

\section{Hatalı para koleksiyonerleri arasında iletişim ağı olarak bir platform, bir dernek vs. var midır?}

Kâğlt paralarla ilgilenen koleksiyonerlerin bir derneği var mıdır bilmiyorum. Nümismatik dernekleri vardır belki; ama ben bilmiyorum. Dolayıslyla bir irtibatım olmadı emekli olana dek. Eskiden sadece pul müzayedeleri vardl. Filateli ${ }^{10}$ müzayedeleri vardı, kâğıt para müzayedeleri bile yoktu. Son 20 yıldır kâğıt para müzayedeleri var. Dolayısıyla onların derneklerinin de olduğunu düşünüyorum. İletişim gerçekleştirme durumum sosyal medyadan oluyor genellikle sizinle iletişim kurduğumuz gibi. Bir kişi "Elindekileri satar misın?" diye iletişime geçmişti. Bunun dışında kâğıt para, madeni para katalogları var, oralardan güncel piyasa fiyatlarını takip edebiliyorsun. Bir arkadaşımın "bilgi sayfası" diye bir internet sayfast var. Onu takip ederek bilgi ediniyorum. Ben kendi Facebook sayfamda elimdeki hatalı kâğıt paraları paylaşıyorum. Arkadaşımla üzerine sohbet ediyoruz. Bunlar dışında geçmişte eskicilere haber vererek ellerine pul, kâğıt para geçerse benimle iletişime geçmelerini söylediğim de olmuştur.

16. Antikacılar ellerine hatalı para geçtiğinde sizi bilgilendiriyorlar mı? Bunun dışında müzayede organizasyonlarında satışa hatalı para sunulması söz konusu olduğunda sizi bilgilendiren bir ilgili oluyor mu?

Emekli olduğumdan bu yana koleksiyonlarıma yönelik alımları (çok istisnai durumlar haricinde) durdurduğum için bana ne antikacılar ne de müzayedeciler özel bir bilgilendirme yapmiyorlar. Ben müzayedelerini zaten kataloglarından ve internetten takip ediyorum güncel piyasadan uzak kalmamak amacıyla.

\section{Hatalı kâğıt para koleksiyonunu toplarken yaşadığını bir anınız var mı? Paylaşır misınız?}

Hatalı kâğıt para toplarken ilginç bir anım olmadı. En ilginç anımı ilk satın alma hikâyem (bkz. 8. soru-cevap) olarak değerlendirebilirim.

\section{Hatalı kâğıt paraların piyasaya sürülme nedeni sizce nedir?}

Paraları tabaka tabaka bastıkları için kontrol sırasında gözden kaçmış olabiliyor.

10 Filateli; pul, posta tarihi ve alakalı her şeyle ilgilenen çalışma alanıdır. Erişim adresi: https://kamerstamps.com/ flateli-nedir/ 
Hatal paralara da bu sebeple piyasaya sürülmeden müdahale edilemeyebiliyor. Basim ya da kontrolde fark edilirse zaten yok ediliyor.

19. Koleksiyonunuza ait paralar hangi yıllara aittir? Hatalı paralar en çok hangi tarih aralı̆̆ında mevcuttur?

Yaklaşık iki yüz tane Cumhuriyet Dönemi'ne ait hatalı para koleksiyonum var; fakat yıllara göre bir ayrım ya da özellikle topladı̆̆ım bir yıl yok. Ama şöyle bir bilgi vermem gerekirse ilk dört emisyon ${ }^{11}$ yurt dışında basılmış ve onlarda hata neredeyse yok. Genelde dördüncü emisyondan sonra Türkiye'de basılmış olan paralarda daha fazla hatalı kâğıt paraya rastllyoruz.

\section{Ulusal basında hatalı paralar için astronomik rakamlar istendiği haberlerini görüyoruz. Bu haberlerin gerçeklik payı var mıdır? Çıkan haberlerle ilgili ne düşünüyorsunuz?}

Çıkan haberleri ben de görüyorum, okuyorum. Hatalı paralarla ilgili çıkan haberlerin neredeyse tamamı hatalı paraların fiyatlarlyla ilgili. Fiyatların astronomik olma klsmı değil; ellerinde hatalı para bulunan kişilerin ellerindeki hatalı paralara bilinçsizce (piyasadaki fiyatlandırmadan habersiz olarak) fiyat biçmeleri dikkatimi çeken ve eleştirdiğim bir nokta. Örneğin; bir vatandaşın elinde eski parayla hatalı bir 250 bin olduğu için 250 bin TL'ye satmak istediğini söyleyebiliyor ve tabii ki bu asla gerçekleşmiyor. Dolayısıla çıkan haberlerden vatandaşların, hatalı paraların ne kadara satıldı̆̆ını, müzayede kültürünü bilmeden fiyat biçtikleri anlaşılmaktadır. Gazetecilerin de herhangi bir araştırmaya girişmeksizin bunu aynen haberleştirmesi de ayrı bir sorun ne yazık ki.

\section{Hatalı para koleksiyonculuğunda Türk koleksiyonerlerini dünya koleksiyonerleri arasında nereye koyarsinı??}

Türkiye'de kâğıt para koleksiyonerleri bildiğim kadartyla sergilere, yarışmalara katılmıyorlar ve çok fazla bir şey de bilmiyorlar. Ortada koleksiyonerliği anlatan çok fazla eser de yok. Bunlar dışında nüfusumuz göz önüne alındığında Türkiye'de çok az koleksiyoner var. O da arz talep piyasasını geliştirmiyor. Bu nedenlerle dünyaya kıyasla zayıf olduğumuzu düşünüyorum. Insanlar bilinçlendirilirse hem fiyat hem de koleksiyonerliğe bakış açısında bir değişim ve gelişim gerçekleşebilir diye düşünüyorum.

\section{Para koleksiyonerleri koleksiyonlarını elden çıkarmak istediklerinde nasıl bir süreç takip ederler?}

Ya tüccarlara götürürler ya da müzayedelere koyarlar. Son dönemde sosyal medya üzerinden satış girişimlerine de rastllyorum.

11 Emisyon kelime anlamı olarak çıkarmak, yaymak, tedavüle çıkarmak anlamında kullanılır. Erişim adresi: http:// www.bacagazi.org/?page_id=27 


\section{Hatalı para koleksiyonları herhangi bir kurum bünyesinde kayt altına alınıyor mu?}

Kurumsal olarak kayıt altında tutulan bir yer yok. Zamanında merkez bankasında çalışan bir arkadaşıma merkez bankası bünyesinde hatalı para sergisi açmaları şeklinde bir fikir vermiştim; fakat bu fikri verirken ol(a)mayacă̆ını da biliyordum. Çünkü banka "ben hatalı para bastım ve bunu fark etmedim, bir de piyasaya sürdüm, sonra da bunları piyasadan / koleksiyonerlerden topladım ve sergi açtım." demek istemez. Ama benim hatalı paraları (koleksiyonerler ile iletişime geçerek) bir araya getirme amacıla bir site açma fikrim var.

\section{Elinizdeki koleksiyonun efemera olduğunu biliyor musunuz?}

Evet, biliyorum; fakat hatal para koleksiyonunu ya da diğer koleksiyonlart oluşturmaya başlarken (otuz, otuz beş sene önce) efemera gibi bir kavramın olduğuna / ne olduğuna dair bir bilgim yoktu. Efemera kavramını yaklaşık on yıl önce koleksiyonerlerle bir aradayken duydum. Onlar koleksiyon parçalarının efemera olduğunu söylediler. Efemera, gündelik yaşama ait "ıvır zıvır" olarak nitelendirilebilecek kısa ömürlü, geçici her şeyi ifade eden bir tanımlamadır. Efemera kavramı ülkemizde oldukça yeni bir kavram. Ben de dediğim gibi on, on beş yıl önce tanışmıştım bu kavramla. Şimdilerde bu konuda bir dergi bile çıkıyor.

\section{Efemera türleri hakkında ne düşünüyorsunuz?}

Benim çok çeşitli koleksiyonlarım mevcut. Öncelikle pullarla başladım. Pul, hatalı pullar, spesimenler, ${ }^{12}$ zarflar, Kuzey Kıbris Türk Cumhuriyet pullarl, antiyeler, ${ }^{13}$ karpostallar, Fenerbahçe ile ilgili hemen her şey ve hatalı / spesimen kâğlt paralar. Bir önceki soruda (soru 24) verdiğim tanıma bakıldığında çok fazla sayıda türü olabileceğini kolaylıkla anlayabiliyoruz.

\section{Medyada efemera ile ilgili çıkan haberleri biriktiriyor musunuz?}

Efemerayla ilgili çıkan haberleri takip ediyorum; fakat biriktirmiyorum.

\section{Efemera ile ilgili dernek gibi platformlar hakkında bir bilginiz ya da üyeliğiniz var midır? \\ Öyle bir dernek ya da bir platforma üye değilim. Var mıdır onu bilmiyorum ama müzayedeleri ve dergisi var. O nedenle bir dernek de olacă̆ını tahmin ediyorum.}

12 Spesimen, örnek, numune. Erişim adresi: https://www.nedirnedemek.com/spesimen-ne-demek

13 Antiye, üzerinde pul baskısı bulunan posta kartlarına verilen isimdir. Erişim adresi: http://anlami-nedir.com/ antiye 


\section{SONUÇ}

Çalışmada, hem literatür araştırması sonucu elde edilen bilgiler hem de koleksiyoner Sayın Ülkü Feyyaz TAKTAK ile yapılan görüşme neticesinde;

- Koleksiyonlar, koleksiyonerlerin genel olarak kişisel zevklerini ya da hobi anlayışlarını yansıtsa da koleksiyonların birer bilgi kaynakları olduğu, gerçek koleksiyonerlerin de koleksiyon oluştururken esas amaçlarının bir konuyu derinlemesine incelemek olduğu,

- Efemera türlerinden biri olan hatalı kâğıt para koleksiyonlarının, kâğıt paralar basılırken birçok açıdan (nümaratör hatalar, basım hataları, kesim hataları, filigran hatalar, emniyet teli hataları gibi) yapılan hatalar hakkında bilgi verdiği,

- Yurt dışında basılan T.C. paralarında neredeyse hiç hata olmadığı, hataların daha çok Türkiye'de basılan (4. emisyondan sonra) T.C. paralarında olduğu,

- Genel olarak koleksiyonerlerin efemera kavramını, koleksiyon parçalarının birer efemera türü olduğunu bildikleri,

- Hatalı paraların sahte para olmadığı, ikisi arasında ayırt edici temel özellikler olduğu,

- Hatalı paralara sahip olan ama koleksiyoner olmayan kişilerin hatalı paralar konusunda bilinçsiz oldukları ve o paraları elden çıkarırken bilinçsizce bir fiyat biçtikleri, koleksiyonerlik ve müzayede anlayışından uzak oldukları,

- Koleksiyonerler arasında sosyal medya aracılığı ve köşe yazıları ile iletişime geçildiği,

- Hatalı kâğıt paraların kayıt altına alındığı bir sistemin olmadığı,

- Koleksiyonların satın alınması hususunda Türkiye'de yeterince yöntem ve bilgi sahibi olunmadığg,

- Para koleksiyonerlerin çoğunun hatalı para koleksiyonlarından bihaber oldukları,

- Hatalı para koleksiyonculuğu ile ilgili yapılan bilgilendirme çalışmalarının (seminer verme, sosyal medya aracılığı ile bilgi paylaşımları gibi) koleksiyonerlerin hatalı kâğıt para koleksiyonculuğu hakkında bilgi sahibi olmalarını sağlamalarına yardımcı olduğu,

- Hatalı kâğıt para koleksiyonun düzenlenmesi, saklanması, korunması, noktasında standart yöntemin ortaya konmadığ 1 , koleksiyonerlerin kendi yöntemleriyle bu işlemleri gerçekleştirdikleri sonuçlarına varılması mümkündür.

Hatalı kâğıt para koleksiyonları 1şı̆̆ında koleksiyon ve efemera ile ilgili aşağıdaki gibi öneriler sunulabilir; 
- Koleksiyonerlik hakkında daha fazla bilgi sahibi olmak adına koleksiyon türü ne olursa olsun tüm koleksiyonerlerin iletişim kuracağ kurulmalıdır, seminerlerin verilme sıklığı artırılmalıdır.

- Verilecek seminerlerde ve oluşturulacak bilgi ağında koleksiyonculukla birlikte efemera hakkında da bilgi paylaşımında bulunulmalıdır.

- Koleksiyonların bilgi ve belge yöneticileri tarafından -bilgi kaynağı olma özellikleriyle- sık sık ele alınmalıdır.

- Türkiye'de müzayede kültürünün yerleşmesi için bilgilendirme gerçekleştirilmelidir.

- Hatalı kâğıt para koleksiyonlarının verdiği bilgilerin (en çok hangi türde hatalar görülmektedir ve sebepleri, kâğıt paraların hangi yıllarında daha çok hatalar görüldüğü, yurt dışında basılan T.C. kâğıt paralarda hataların Türkiye'de basılan T.C. paralardan az olmasının nedenleri gibi) koleksiyonerler, arşivistler ve kütüphaneciler ile işbirliği içerisinde sistemli ve ayrıntılı bir şekilde ortaya konmalıdır.

Toplumun sosyal ve kültürel geçmişi hakkında önemli ve detaylı bilgiler veren bilgi kaynağı olması sebebiyle efemera önemlidir. Koleksiyonların içerdiği malzemelerden dolayı efemera olma özellikleri mevcuttur. Bu durum hem koleksiyonların hem de efemeranın arşiv ve kütüphane alanlarında gündemden düşmeyen bir konu olmasını gerektirmektedir. Efemera konusu için koleksiyonerler ile işbirliği içerisinde yapılacak olan her türlü faaliyet ve çalışmaların, arşiv ve kütüphanecilik alanına önemli katkılar sağlayacağı açıktır.

Hakem Değerlendirmesi: Dış bağımsız.

Çıkar Çatışması: Yazar çıkar çatışması bildirmemiştir.

Finansal Destek: Yazar bu çalışma için finansal destek almadığını beyan etmiştir.

Peer-review: Externally peer-reviewed.

Conflict of Interest: The author has no conflict of interest to declare.

Grant Support: The author declared that this study has received no financial support.

\section{Kaynakça/References}

Buyurgan, T. (2007). Aykırı paralar: denemeler, erörler, sahteler, para-biletler, paramsılar. İstanbul: Tunç Buyurgan Koleksiyonu.

Çantay, D. (2019). Koleksiyonerlik [Blog yazıs1]. Erişim adresi: https://www.ankaraantikacilik.com/blog/89/ koleksiyonerlik

Darphane ve Damga Matbaası Genel Müdürlüğü Paranın Tarihi. (2018). Erişim adresi: https://www.darphane. gov.tr/paranin-tarihi 
Efemera. (2019). Erişim adresi: http://www.turkcebilgi.com/efemera

Efemera Nedir?. (2019). Erişim adresi: http://www.muzayededunyası.com/bilgi-bankasi/efemera-nedir/

Eskier, U., (2020). Koleksiyonculuk nedir? (Özellikleri, çeşitleri) [Blog yazısı]. Erişim adresi: https://www. makaleler.com/koleksiyonculuk-nedir

Karakaş, S., Rukanc1, F. ve Anameriç, H. (2009). Belge yönetimi ve arşiv terimleri sözlüğ̈̈. Ankara: Devlet Arşivleri Genel Müdürlüğü.

Moses Pearce, R. (2005). A glossary of archival and record terminology. Chicago: The Society of American Archivists.

Odabaş, H. (2018, Nisan). Arşivlerde ve kütüphanelerde yerel kültürel değerlerin korunması bağlamında efemera koleksiyonuna karşı sorumluluklar. I. Uluslararası Efemera Çalışmaları Sempozyumunda sunulan bildiri, Ankara. Erişim adresi: https://odabashuseyin.wordpress.com/yayinlar/

Özdizbay, A. E. (2017). Nümismatik nedir? [Blog yazısı]. Erişim adresi: https://www.tarihbilimleri.com/ numismatik/numismatik-nedir

Rickards, A. (2018). Encyclopedia of ephemera: A guide to the fragmentary documents of everyday life for the collector, curator and historian. Twyman, T. (Ed.). Abingdon: Routledge. Erişim adresi: https://books. google.com.tr/books/about/The_Encyclopedia_of_Ephemera.html?id=T4O3vIHhjoUC\&redir_esc=y

Sarısır, S. (2020). İktisat tarihi yazımında, efemera olarak tahvil ve hisse senetlerinin önemi (Osmanlı'dan Cumhuriyet'e örneklerle). Tarih Araştırmaları Dergisi, 39(67), 569-583. Erişim adresi: https://dergipark. org.tr/tr/pub/tariharastirmalari/issue/53162/620876

Somer, Ş. N. ve Keskin, İ. (2012). Bir bilgi kaynağı olarak efemera ve türleri. Bilgi Dünyasl, 13(2), $437-456$.

Tarihin Faydalandığı Bilim Dalları (Coğrafya, Arkeoloji...). (2020). Erişim tarihi: http://tarihrehberiniz.blogcu. com/tarihin-faydalandigi-bilim-dallari-cografya-arkeoloji/5396097

Türk Dil Kurumu. (2020). Erişim adresi: https://sozluk.gov.tr/

Türk Nümismatik Derneği. (2014). Erişim adresi: https://web.archive.org/web/20140214141628/http://www. turknumismatik.org.tr/

Young, T. G. (2003). Evidence: Toward a library definition of ephemera. RBM: A Journal of Rare Books, Manuscripts, and Cultural Heritage, 4(1), 11-26. Erişim adresi: https://rbm.acrl.org/index.php/rbm/ article/view/214 


\section{EKLER}

\section{Ek 1:}

Ek 1'de belirtilen kâğıt parada, paraya seri numarasının basılmamasından kaynaklanan bir hata söz konusudur.

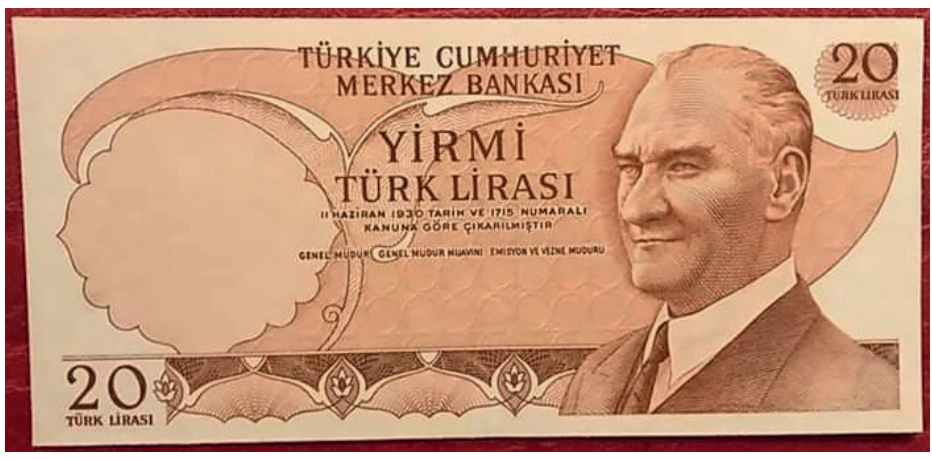

\section{Ek 2:}

Ek 2'de belirtilen kâğıt parada, paranın köşesinde, yanlış kesimden kaynaklanan (fazlalık) bir hata söz konusudur.

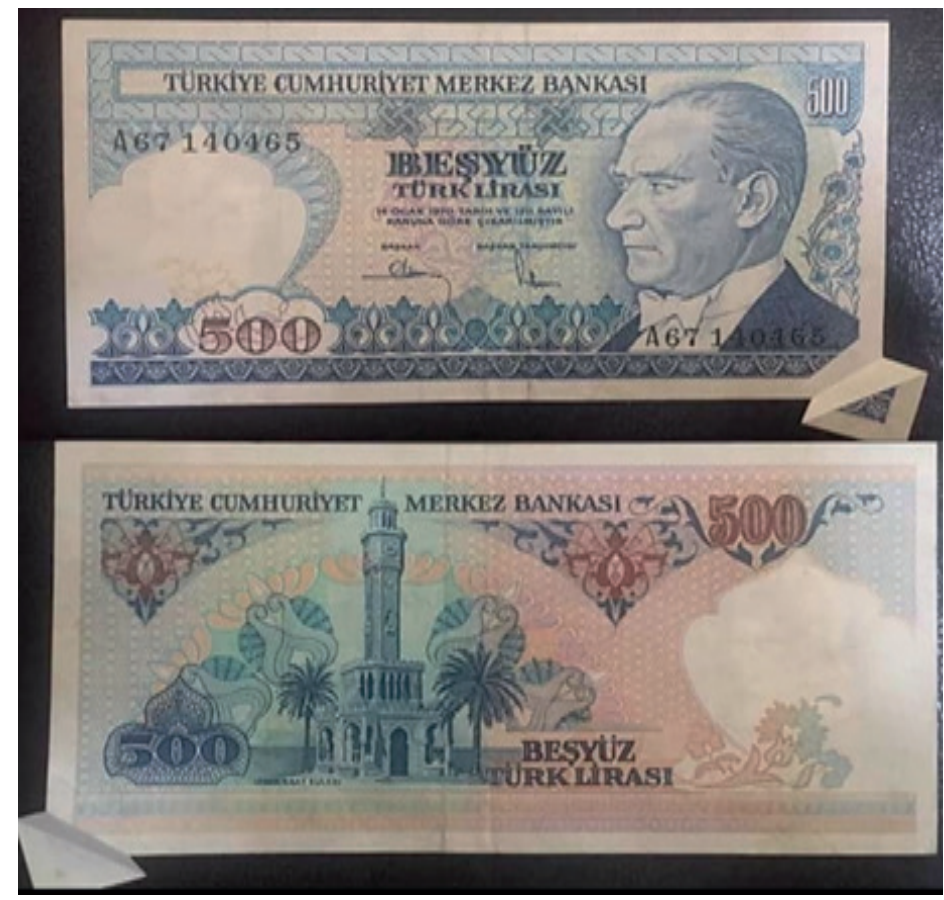




\section{Ek 3:}

Ek 3’te belirtilen kâğıt parada, paranın arka yüzünün basılmamasından kaynaklı bir hata söz konusudur.

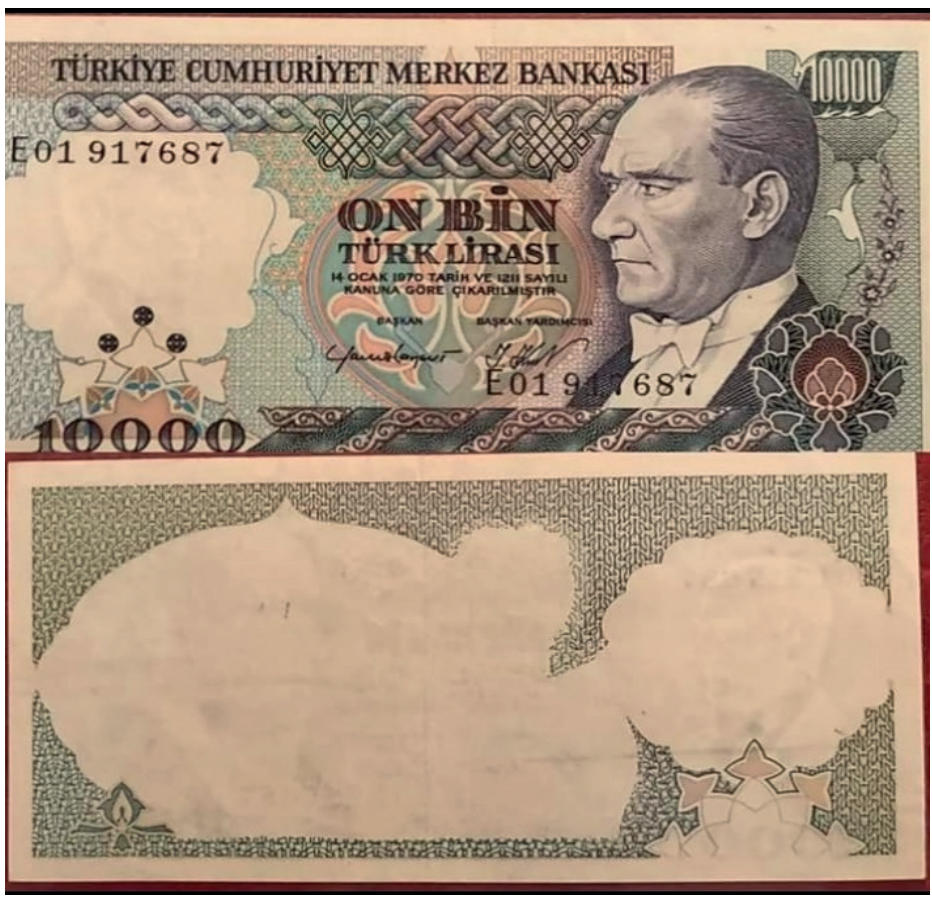

Ek 4:

Ek 4'de belirtilen kâğıt parada, paranın bir yüzüne çift basımdan kaynaklanan bir hata söz konusudur.

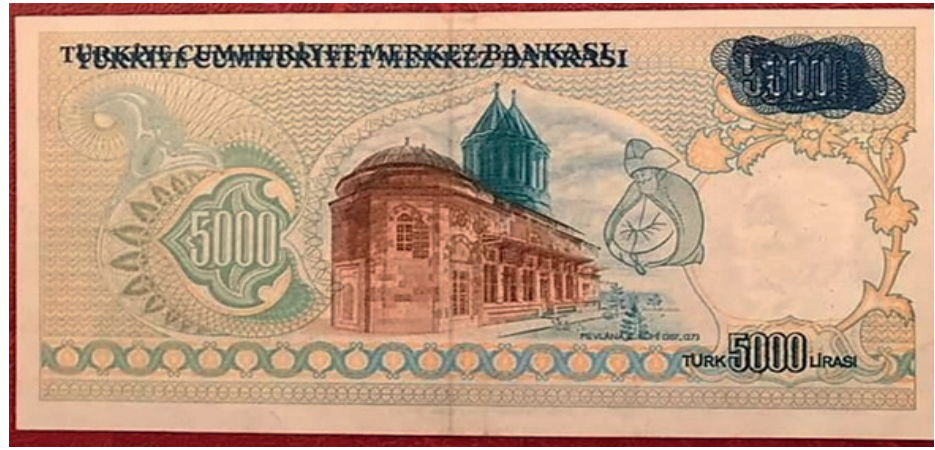




\section{Ek 5:}

Ek 5'te belirtilen kâğıt parada, paranın köşesinde, yanlış kesimden kaynaklanan (eksiklik) bir hata söz konusudur.

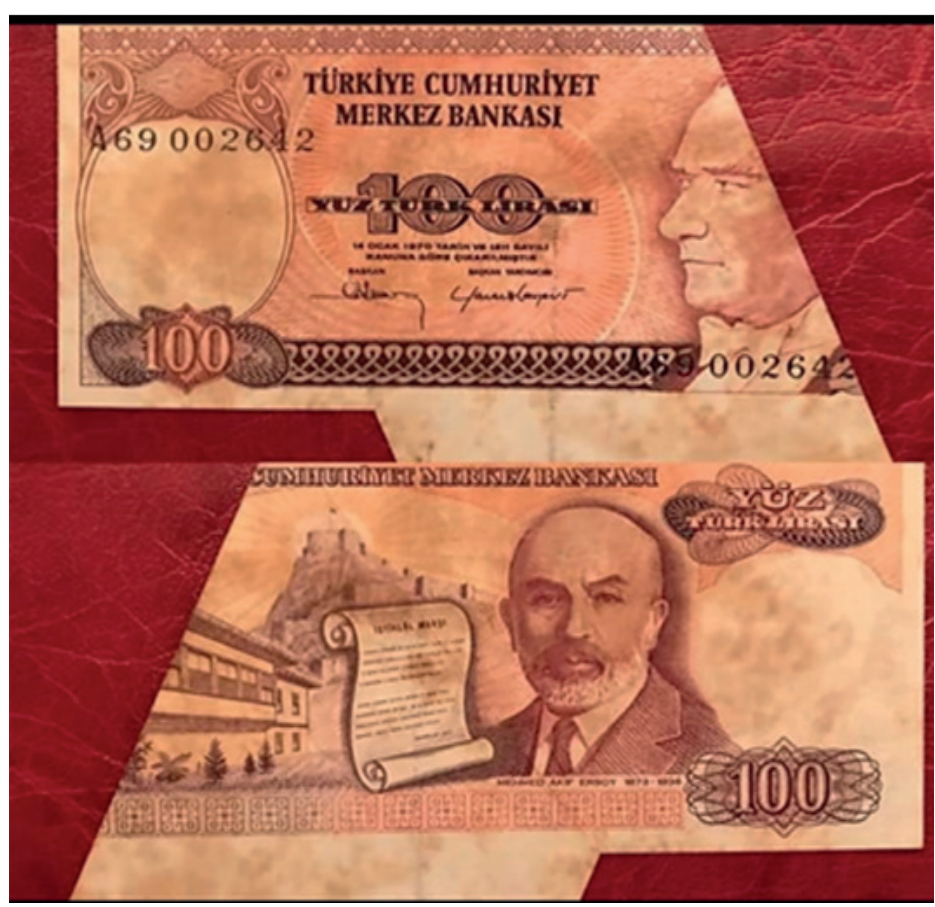

